\title{
PENGARUH MANAJEMEN RISIKO KREDIT TERHADAP PROFITABILITAS BANK PERKREDITAN RAKYAT DI KEPULAUAN RIAU
}

\author{
Serly* dan Edy Kurniawan* \\ *Program Studi Akuntansi, Universitas Internasional Batam \\ Email: serly@uib.ac.id;Edy.kurniawan1907@gmail.com
}

\begin{abstract}
This study is aimed to identify the effect of credit risk management on the profitability of Rural Credit Banks in Riau Islands. Measurement of profitability in this dependent variable is in a form of return on assets and there are independent variables in this study in the form of capital adequacy ratio, non-performing loans, bank size, liquidity, inefficiency, and inflation.

38 banking companies are sampled in this study, all registered in the Financial Services Authority within the 2014-2018 period. Purposing sampling method is used to determine the acquired samples. Data collection is done by researching, analyzing, and studying the financial statements of the banking and then processed with the help of the Eviews software.

The results showed the capital adequacy ratio, bank size, and inefficiency has a significant negative effect on return on assets. While the liquidity variable has a significant positive effect on return on assets and non-performing loan variables, while inflation do not have a significant relationship with return on assets.
\end{abstract}

Keywords: profitability, credit risk, rural bank

\section{PENDAHULUAN}

Lembaga keuangan bank merupakan sistem keuangan dalam posisi finansial dan pertumbuhan ekonomi suatu negara dengan memiliki komponen dasar yang berperan penting. Pembiayaan ekonomi dan efektivitas fungsi atas kegiatan lembaga perbankan memberikan keuntungan dalam sistem ekonomi secara keseluruhan. Kesehatan dan efisiensi dalam kinerja keuangan bank menjadi kunci penting dalam pembangunan ekonomi. Kontribusi yang dapat diberikan lembaga perbankan yang menguntungkan dan sehat adalah mampu menghambat guncangan negatif dan menjaga stabilitas sistem keuangan (Hakimi \& Zaghdoudi, 2017; Wireko \& Forson, 2017; Darayseh \& Chazi, 2018).

Bank menghadapi berbagai risiko dalam melaksanakan kegiatan usaha sebagai intermediasi atas menyalurkan pinjaman dan menerima simpanan yang dapat mempengaruhi tingkat kinerja bank. Pengukuran tingkat profitabilitas untuk mengetahui kinerja suatu bank melalui return on equity (ROE), return on asset (ROA), dan net interest margin (NIM). Pentingnya tingkat profitabilitas bagi suatu perbankan adalah untuk mengukur efektivitas pengelolaan manajemen dan kemampuan perusahaan dalam mencapai laba demi memaksimalkan kekayaan pemegang saham (Agustini, Wiagustini, \& Purbawangsa, 2017; Mendoza \& Rivera, 2017).

Berdasarkan laporan dari Otoritas Jasa Keuangan (OJK) pada tahun 2018, penurunan kinerja perusahaan Bank Perkreditan Rakyat (BPR) di Indonesia dimulai dari tahun 2014 sebesar 2,98\% menjadi 2,48\% pada tahun 2018. Menurunnya kinerja perbankan di Indonesia disebabkan oleh berbagai faktor seperti penurunan pertumbuhan kredit dan kenaikan tingkat kredit bermasalah. Tingkat kredit bermasalah merupakan risiko kredit yang dihadapi perbankan yang dapat dilihat dari tingkat non performing loan. Berdasarkan latar belakang di atas, adanya ketertarikan 
peneliti dalam melakukan penelitian terkait faktor yang memengaruhi profitabilitas BPR di Kepulauan Riau.

Penelitian ini dilakukan dengan tujuan agara manajemen perbankan dalam pengambilan kebijakan finansial untuk meningkatkan profitabilitas bank khususnya Bank Perkreditan Rakyat yang akan meningkatkan penilaian bank. Selain itu, memberikan tambahan kepustakaan, memberikan sumbangan pemikiran serta pemecahannya, khususnya mengenai pengaruh manajemen risiko kredit terhadap profitabilitas BPR di Kepulauan Riau.

\section{KERANGKA TEORITIS PERUMUSAN HIPOTESIS}

\subsection{Pengertian Bank}

Bank adalah lembaga perantara keuangan dengan mempunyai aktivitas operasional memperoleh dana dalam bentuk deposito, tabungan, simpanan, dan giro yang bersumber dari masyarakat yang memiliki kelebihan dana serta melakukan penyaluran pinjaman kepada masyarakat yang memiliki kekurangan dana dengan penjualan produk perbankan sehingga akan meningkatkan taraf hidup rakyat bank (Pasaribu, Kowanda, \& Paramitha, 2015; Haritsman \& Usman, 2017).

BPR adalah lembaga keuangan yang menjalankan aktivitas usaha berasas prinsip syariah atau secara konvensional, tetapi tidak mengoperasikan jasa dalam lalu lintas pembayaran (Kasmir, 2012). Ruang lingkup kegiatan usaha BPR mempunyai batasan yang diperbolehkan oleh otoritas keuangan sehingga sumber penghasilan kegiatan operasional BPR bertumpu pada selisih antara pendapatan bunga kredit dengan biaya bunga simpanan (Afriyeni, 2017).

\subsection{Fungsi dan Kegiatan BPR}

BPR sebagai badan keuangan dengan melakukan aktivitas operasional sebagai perantara keuangan dengan memperoleh dana pihak ketiga serta melaksanakan penyaluran dalam fasilitas kredit. Adapun fungsi penting dari Bank Perkreditan Rakyat adalah sebagai solusi keuangan bersama dengan memberikan bantuan kredit kepada masyarakat dalam berbagai macam kegiatan ekonomi (Wirawan, Jufrizen, \& Rambe, 2018).

\subsection{Manajemen Risiko dan Profitabilitas BPR}

Penurunan kinerja keuangan bank salah satunya dapat disebabkan oleh kurangnya pengendalian manajemen risiko dalam kegiatan usaha perbankan. Manajemen risiko kredit merupakan faktor utama dalam penentuan kinerja keuangan perbankan. Kegiatan usaha perbankan dalam pemberian kredit kepada nasabah akan menimbulkan berbagai risiko, yaitu berupa tidak lancarnya pembayaran kewajiban pembayaran pokok dan bunga pinjaman nasabah sehingga bank akan mengalami penurunan profitabilitas (Pasaribu et al., 2015). Dengan diterapkannya manajemen risiko bank agar dapat membantu pihak bank dalam mengidentifikasi permasalahan yang timbul dengan memelihara bank melalui self assessment serta membuat tindakan untuk mempermudah dalam penentuan kebijakan prinsip bank (Attar, Islahuddin, \& Shabri, 2014).

\subsection{Hipotesis}

Perumusan hipotesis dalam penelitian ini dapat dijelaskan sebagai berikut:

$\mathrm{H}_{1}$ : Adanya pengaruh signifikan positif antara capital adequacy ratio terhadap profitabilitas.

$\mathrm{H}_{2}$ : Adanya pengaruh signifikan negatif antara non performing loan terhadap profitabilitas.

$\mathrm{H}_{3}$ : Adanya pengaruh signifikan positif antara bank size terhadap profitabilitas.

$\mathrm{H}_{4}$ : Adanya pengaruh signifikan positif antara liquidity terhadap profitabilitas.

$\mathrm{H}_{5}$ : Adanya pengaruh signifikan negatif antara inefficiency terhadap profitabilitas.

$\mathrm{H}_{6}$ : Adanya pengaruh signifikan negatif antara inflasi terhadap profitabilitas. 


\section{METODOLOGI PENELITIAN}

Rancangan ini adalah penelitian kuantitatif untuk menganalisa data memakai metode statistika serta mengutamakan uji teori dalam pengukuran variabel dengan angka. Penelitian ini termasuk penemuan dasar dengan tujuan pengembangan dan pengevaluasian konsep teoritis serta tidak terpengaruh secara langsung dalam penentuan prosedur-prosedur dan tindakantindakan tertentu serta dapat digunakan sebagai pemecahan permasalahan secara teroritis (Indriantoro \& Supomo, 2013).

Rancangan ini bersifat sebagai penelitian historis dan penelitian kausal komparatif. Penelitian historis adalah penelitian terhadap permasalahan yang berhubungan dengan kejadian masa lampau. Penelitian kausal komparatif merupakan penelitian yang mengidentifikasikan dan menjelaskan fenomena ikatan sebab-akibat antara berbagai variabel (Indriantoro \& Supomo, 2013).

Sampel perusahaan perbankan pada penelitian ini telah terdaftar di OJK. Data laporan keuangan tahunan merupakan objek penelitian dengan periode pengamatan 20142018. Sampel penelitian dipilih berdasarkan kriteria atau pertimbangan tertentu yang disebut sebagai metode purposive sampling.

\subsection{Variabel Dependen}

Menurut Sartono (2014), profitabilitas merupakan kemampuan bank dalam menilai efektivitas perbankan untuk mencapai profit yang berhubungan dengan penjualan, modal, ataupun total aktiva.

Pengukuran variabel profitabilitas menurut Ovami (2017) adalah bertujuan untuk menilai kinerja suatu bank dalam memperoleh profit yang dapat diukur menggunakan rasio ROA dengan memanfaatkan aktiva yang dimilikinya. Menurut Pratiwi dan Suryantini (2018), rasio ROA dapat dirumuskan:

$$
\mathrm{ROA}=\frac{\text { Laba sebelum pajak }}{\text { Rata-rata total aset }} \times 100 \%
$$

\subsection{Variabel Independen}

\subsubsection{Capital Adequacy Ratio (CAR)}

Menurut Zulfiah dan Susilowibowo (2014), CAR merupakan rasio perbankan untuk menilai tingkat kecukupan modal dari suatu perbankan dalam menunjang aktiva yang terdapat risiko. Menurut Wireko dan Forson (2017), cara pengukuran CAR adalah:

$$
\mathrm{CAR}=\frac{\text { Jumlah modal }}{\text { Aktiva Tertimbang Menurut Risiko (ATMR) }} \times 100 \%
$$

\subsubsection{Non Performing Loan (NPL)}

Menurut Putrianingsih dan Yulianto (2016), NPL adalah rasio suatu bank yang memberikan informasi mengenai sejauh mana kemampuan bank untuk meminimalkan kredit bermasalah yang dihadapi. Menurut Chou dan Buchdadi (2016), rumus untuk mengukur NPL adalah:

$$
\mathrm{NPL}=\frac{\text { Jumlah kredit bermasalah }}{\text { Jumlah kredit yang diberikan }} \times 100 \%
$$

\subsubsection{Bank Size}

Menurut Adnan et al. (2016), ukuran perusahaan atau bank size merupakan suatu takaran yang dapat mengelompokkan besar kecilnya suatu perbankan. Total aset yang sifatnya lebih jangka panjang menjadi salah satu indikator dalam ukuran bank (Astrini, Suwendra, \& Suwarna, 2014). Adapun pengukuran bank size menurut Prasetiono (2016) adalah:

$$
\text { Bank Size = Ln Total Assets }
$$

\subsubsection{Liquidity}

Menurut Lubis et al. (2017), LDR merupakan rasio keuangan perbankan untuk mengetahui tingkat likuiditas bank dalam mengukur sejauh mana simpanan digunakan untuk pemberian kredit. Rumus perhitungan LDR menurut Afriyeni (2017) adalah:

$\mathrm{LDR}=\frac{\text { Total kredit yang diberikan }}{\text { Total dana pihak ketiga }} \times 100 \%$

\subsubsection{Inefficiency}

Menurut Nihayati, Wahyudi, dan Syaichu (2014), biaya operasional 
pendapatan operasional merupakan suatu indikator dalam pengukuran tingkat efisiensi suatu bank dengan membandingkan biaya operasional terhadap pendapatan operasional. Tingkat efisiensi merupakan bagian yang terpenting pada manajemen bank karena berhubungan dengan pengeluaran dan pemasukan dalam melaksanakan kegiatan operasionalnya. Menurut Nihayati et al. (2014), cara pengukuran BOPO adalah:

$$
\mathrm{BOPO}=\frac{\text { Biaya operasional }}{\text { Pendapatan operasional }} \times 100 \%
$$

\subsubsection{Inflasi}

\section{HASIL PENELITIAN}

\subsection{Statistik Deskriptif}

Tabel 1

Hasil Uji Statistik Deskriptif

\begin{tabular}{|l|r|r|r|r|r|}
\hline \multicolumn{1}{|c|}{ Variabel } & N & \multicolumn{1}{c|}{ Minimum } & \multicolumn{1}{c|}{ Maximum } & \multicolumn{1}{c|}{ Mean } & $\begin{array}{c}\text { Std. } \\
\text { Deviation }\end{array}$ \\
\hline Return On Assets (ROA) & 179 & $-0,1292$ & 0,0927 & 0,0301 & 0,0267 \\
\hline Capital Adequacy Ratio (CAR) & 179 & 0,0808 & 0,9228 & 0,2250 & 0,1438 \\
\hline Non Performing Loan (NPL) & 179 & 0,0000 & 0,2078 & 0,0393 & 0,0340 \\
\hline Bank Size (dalam jutaan) & 179 & 9.101 & 1.533 .832 & 151.231 & 0,9055 \\
\hline Liquidity & 179 & 0,1642 & 0,9963 & 0,7632 & 0,1120 \\
\hline Inefficiency & 179 & 0,5363 & 1,5268 & 0,8162 & 0,1337 \\
\hline Inflasi & 179 & 0,0347 & 0,0759 & 0,0458 & 0,0152 \\
\hline Valid N (listwise) & 179 & & & & \\
\hline
\end{tabular}

Sumber: Data penelitian diolah (2019)

ROA memiliki nilai minimum sebesar $-12,92 \%$ hasil ini berarti terdapat BPR yang terdaftar di OJK yang memiliki kinerja rendah dalam mendapatkan profit. Sedangkan nilai maximum variabel dependen ROA sebesar 9,27\% hasil ini berarti adanya BPR di OJK yang memiliki kinerja yang bagus dalam memperoleh profit dari aktiva yang dimiliki. Rata-rata nilai dependen ROA pada BPR Kepulauan Riau sebesar 3,01\%. Nilai rata-rata tersebut dapat dikatakan ideal karena ROA berada diatas $1,5 \%$.

CAR memiliki nilai terendah sebesar $8,08 \%$ dan nilai tertinggi sebesar 92,28\%. Nilai ini membuktikan adanya BPR yang memiliki tingkat kecukupan modal yang tinggi dan belum disalurkan dananya dalam fasilitas kredit kepada masyarakat maupun penempatan deposito pada bank lain. Ratarata nilai CAR BPR Kepulauan Riau yang
Inflasi merupakan situasi dimana peningkatan harga secara terus menerus dan secara umum berhubungan dengan komponen pasar yang diakibatkan oleh berbagai faktor seperti meningkatnya kebutuhan masyarakat dan menurunnya nilai mata uang yang disebabkan oleh adanya dampak krisis moneter. Rumus perhitungan inflasi menurut Zulfiah dan Susilowibowo (2014) adalah:

$$
\text { Inflasi }=\frac{\left(\mathrm{IHK}_{\mathrm{t}}-\mathrm{IHK}_{\mathrm{t}-1}\right)}{\mathrm{IHK}_{\mathrm{t}-1}} \times 100 \%
$$


perusahaan BPR Kepulauan Riau dari total aset tergolong besar.

Liquidity memiliki data terendah sebesar $16,42 \%$ dan data tertinggi sebesar 99,63\%. Rata-rata nilai LDR pada BPR Kepulauan Riau yang terdaftar di OJK sebesar 76,32\%. Nilai tersebut menunjukkan bahwa rata-rata BPR Kepulauan Riau menggunakan dana simpanannya secara efektif dalam melakukan penyaluran kredit kepada masyarakat.

Inefficiency memiliki nilai maximum sebesar $152,68 \%$ dan nilai minimum sebesar $53,63 \%$. Hasil ini membuktikan adanya BPR yang melakukan kegiatan operasionalnya secara kurang efisien. Bank yang tidak efisien merupakan bank yang tidak mampu meningkatkan pendapatan operasi dan menekankan biaya operasi bank tersebut. Rata-rata nilai BOPO BPR Kepulauan Riau yang terdaftar di OJK sebesar $81,62 \%$. Nilai rata-rata telah mentaati Peraturan Bank Indonesia Nomor 10/15/PBI/2008 yang menetapkan rasio BOPO yang sehat tidak melebihi dari $90 \%$.

Hasil variabel inflasi berdasarkan uji statistik deskriptif menunjukkan bahwa kegiatan inflasi terendah dialami pada tahun 2018 sebesar 3,47\% dan inflasi tertinggi pada tahun 2014 sebesar 7,59\% dengan pengujian inflasi selama 5 tahun. Rata-rata nilai inflasi yang dialami Indonesia sebesar $4,58 \%$ selama 5 tahun.

\subsection{Hasil Uji Outlier}

Selama periode tahun 2014-tahun 2018 terdapat 43 BPR yang terdaftar di OJK dengan 5 BPR yang tidak sesuai kriteria berupa tidak menyajikan laporan keuangan tahunan. Dengan demikian, sampel dalam penelitian ini berjumlah 38 BPR. Data outlier pada sampel berjumlah 11 data yang merupakan data outlier yang tidak disertakan dalam penelitian sehingga secara keseluruhan terdapat 179 data yang diobservasi.

\subsection{Hasil Uji Chow}

Tabel 2

Hasil Uji Chow

\begin{tabular}{|c|c|c|}
\hline Hasil Uji & Prob. & Kesimpulan \\
\hline Cross-section Chi-square & 0,0000 & Fixed Effect Model \\
\hline
\end{tabular}

Sumber: Data penelitian diolah (2019)

Penggunaan uji chow dapat membuktikan pemilihan model antara pooled least square (PLS) atau fixed effect model (FEM). Dengan melihat hasil probabilitas pada cross-section chi-square menunjukkan hasil probabilitas lebih kecil dari 0,05 yaitu sebesar 0,0000. Apabila nilai probabilitas model regresi data panel pada cross-section chi-square $<0,05$ maka model yang dipakai yaitu FEM, sedangkan jika memakai model PLS maka nilai probabilitas cross-section chi-square $>0,05$.

Pemilihan model regresi data panel terbaik belum dapat dipastikan. Adanya kemungkinan memakai metode random effect model (REM) pada penelitian. Oleh karena itu, diperlukan uji hausman.

\subsection{Hasil Uji Hausman}

Tabel 3

Hasil Uji Hausman

\begin{tabular}{|c|c|c|}
\hline Hasil Uji & Prob. & Kesimpulan \\
\hline Cross-section random & 0,6045 & Random Effect Model \\
\hline
\end{tabular}

Sumber: Data penelitian diolah (2019)

Penggunaan uji hausman untuk mendefinisikan pengujian statistik dalam pemilihan model antara FEM atau REM. Dengan melihat hasil probabilitas pada crosssection random menampilkan hasil sebesar 0,6045 . Hasil ini dapat dikatakan bahwa metode regresi data panel pada penelitian memakai REM. Ditinjau dari nilai probabilitas apabila suatu model regresi panel jika mempunyai nilai probabilitas $<0,05$, maka model regresi yang dipakai ialah FEM. Sedangkan jika mempunyai nilai probabilitas > 0,05, maka model penelitian menggunakan REM.

\subsection{Hasil Uji F}

Tabel 4

Hasil Uji F

\begin{tabular}{|c|c|}
\hline Variabel Dependen & Prob. \\
\hline Return On Assets & 0,0000 \\
\hline
\end{tabular}

Sumber: Data penelitian diolah (2019) 
Penggunaan uji $\mathrm{F}$ untuk menilai hubungan variabel independen secara simultan dalam suatu model terhadap variabel dependen. Nilai signifikansi variabel ROA menghasilkan nilai sebesar 0,0000. Nilai signifikansi $<0,05$, nilai ini dikatakan bahwa capital adequacy ratio, non performing loan, bank size, liquidity, inefficiency, dan inflasi sebagai variabel independen secara simultan berpengaruh terhadap variabel dependen yaitu ROA.

\subsection{Hasil Uji t}

Tabel 5

Hasil Uji $t$

\begin{tabular}{|l|c|c|c|}
\hline \multicolumn{1}{|c|}{ Variabel } & Koefisien Korelasi & Prob. & Kesimpulan \\
\hline CAR & $-0,019330$ & 0,0023 & Signifikan Negatif \\
\hline NPL & $-0,019642$ & 0,2242 & Tidak Signifikan \\
\hline Bank Size & $-0,003891$ & 0,0004 & Signifikan Negatif \\
\hline Liquidity & 0,012112 & 0,0176 & Signifikan Positif \\
\hline Inefficiency & $-0,208666$ & 0,0000 & Signifikan Negatif \\
\hline Inflasi & 0,005374 & 0,8574 & Tidak Signifikan \\
\hline
\end{tabular}

Sumber: Data penelitian diolah (2019)

\section{H1: Adanya pengaruh signifikan positif antara CAR terhadap profitabilitas.}

CAR memiliki nilai probabilitas sebesar 0,0023 dan koefisien regresi $-0,019330$. Pengujian hipotesis pertama $\left(\mathrm{H}_{1}\right)$ tidak terbukti pada penelitian ini. Nilai CAR terdapat hubungan negatif yang signifikan terhadap ROA. Hal ini dikarenakan tingginya kecukupan modal yang dimiliki bank dan dalam menghadapi saingan yang cukup ketat maka bank akan berfokus pada peningkatan aset perusahaan. Semakin meningkatnya permodalan bank dapat menyebabkan penurunan profitabilitas karena demi memenangkan persaingan bank akan berupaya mengoptimalkan modal yang dimiliki. Bank akan menurunkan spread melalui berbagai program promosi demi mencapai pertumbuhan yang diinginkan dengan cara menurunkan suku bunga kredit dan menaikkan suku bunga deposito sampai titik base of lending rate bank tersebut (Maheswari \& Sudirman, 2014; Septiani \& Lestari, 2016). Hipotesis pertama dalam peneliti ini serupa dengan penemuan Wireko dan Forson (2017) dan Lubis et al. (2017).

\section{H2: Adanya pengaruh signifikan negatif antara NPL terhadap profitabilitas.}

NPL memiliki nilai probabilitas sebesar 0,2243 dengan koefisien regresi $-0,019642$. Pengujian hipotesis kedua $\left(\mathrm{H}_{2}\right)$ tidak terbukti pada penelitian ini. Hasil di atas menunjukkan bahwa NPL mempunyai ikatan negatif yang tidak signifikan terhadap ROA. Hal ini dikarenakan rata-rata rasio NPL yang terjadi kecil dari 5\% yang membuktikan bahwa BPR Kepulauan Riau mengalami risiko kredit yang rendah, tetapi tidak memberikan dampak peningkatan pada ROA. Bank memberikan fasilitas kredit berdasarkan prinsip kehati-hatian dengan memperhatikan kualitas kredit yang diberikan sehingga profitabilitas yang dialami perbankan tidak terpengaruh oleh NPL (Septiani \& Lestari, 2016; Ovami, 2017).

Hasil ini mendukung dengan hasil penemuan Saeed dan Zahid (2016), Ishak et al. (2016), Mahmud et al. (2016), Ovami (2017), Assfaw (2018), Lelissa dan Kuhil (2018), dan Abdeldayem dan El-Sherbiney (2018).

\section{H3: Adanya pengaruh signifikan positif antara bank size terhadap profitabilitas.}

Bank size memiliki pengaruh signifikan positif terhadap ROA tidak terbukti dalam penelitan ini. Variabel bank size terhadap ROA mempunyai nilai 
signifikansi 0,0004 dan koefisien korelasi sebesar -0,003891. Nilai ini membuktikan bahwa variabel bank size adanya pengaruh signifikan negarif terhadap ROA. Hal tersebut dikarenakan ukuran perbankan yang lebih besar dapat menyebabkan peningkatan biaya operasional bank tersebut sehingga dapat menurunkan profitabilitas bank. Bank yang mempunyai jumlah aset yang tinggi dalam memperoleh dana dari masyarakat agar dana yang terhimpun dari masyarakat dapat dalam jumlah banyak maka dapat dilakukan dengan cara meningkatkan suku bunga simpanan dalam hal ini juga meningkatkan biaya yang harus ditanggung oleh perbankan ikut meningkat seiring dengan pembayaran bunga simpanan (Kadek Widya Astutiningsih, 2019).

Hasil penelitian ini sejalan dengan penemuan Mahmud et al. (2016), AlRdaydeh et al. (2017), Abdeldayem dan ElSherbiney (2018), dan Mohanty dan Krishnankutty (2018).

\section{H4: Adanya pengaruh signifikan positif antara liquidity terhadap profitabilitas.}

Liquidity memiliki nilai probabilitas 0,0176 dan koefisien regresi 0,012111. Pengujian hipotesis keempat $\left(\mathrm{H}_{4}\right)$ terbukti pada penelitian ini. Hubungan positif ini dapat diartikan apabila LDR turun maka ROA turun dan sebaliknya, apabila LDR naik maka ROA akan naik. Banyaknya dana yang disampaikan kepada masyarakat dalam hal ini menjelaskan bahwa bank lebih kuat mengeluarkan simpanannya dalam fasilitas kredit dan semakin banyak pendapatan yang dihasilkan oleh bank. Penyaluran kredit yang disalurkan secara efektif dan memiliki kualitas kredit yang bagus memberikan kontribusi penghasilan bunga yang besar sehingga dapat menaikkan profitabilitas (Pasaribu et al., 2015; Agustini et al., 2017).

Hasil penemuan di atas sesuai dengan penemuan Syafi'i dan Rusliati (2016), Agustini et al. (2017), Pratiwi dan Suryantini (2018), dan Sarwar et al. (2018).

\section{H5: Adanya pengaruh signifikan negatif antara inefficiency terhadap profitabilitas.}

Inefficiency menampilkan nilai koefisien -0,208667 dan probabilitas sebesar 0,0000 . Pengujian hipotesis kelima $\left(\mathrm{H}_{5}\right)$ terbukti pada penelitian ini. Hubungan negatif ini dapat diartikan ketika nilai BOPO mengalami kenaikan maka profitabilitas akan terjadi penurunan. Hal ini dikarenakan laba atau penghasilan yang diperoleh oleh bank disebabkan dari efisiensi bank atas kegiatan operasionalnya. Bank yang efisien merupakan bank yang dapat meningkatkan pendapatan operasi dan mampu menekankan biaya operasi perusahaan agar memperoleh keuntungan tertinggi serta terhindar kondisi bank bermasalah. Bank yang melakukan kegiatan operasi dengan efisien dalam hal ini berarti rasio BOPO rendah maka profitabilitas bank akan meningkat. Demikian pula sebaliknya, jika bank tidak melakukan kegiatan operasi secara efisien atau rasio BOPO tinggi maka dapat menyebabkan profitabilitas bank menurun (Zulfiah \& Susilowibowo, 2014; Pasaribu et al., 2015).

Hasil analisis berdasarkan pengujian di atas, dapat dikatakan bahwa hipotesis kelima sejalan dengan penemuan Zulfiah dan Susilowibowo (2014), Pasaribu et al. (2015), Lubis et al. (2017), Ovami (2017), Abdeldayem dan El-Sherbiney (2018), Pratiwi dan Suryantini (2018), dan Mohanty dan Krishnankutty (2018).

\section{H6: Adanya pengaruh signifikan negatif antara inflasi terhadap profitabilitas.}

Inflasi memiliki nilai probabilitas

0,8575 dengan koefisien regresi sebesar 0,005372 . Pengujian hipotesis keenam $\left(\mathrm{H}_{6}\right)$ tidak terbukti pada penelitian ini. Hasil di atas menjelaskan adanya pengaruh tidak signifikan dengan arah hubungan positif antara inflasi terhadap ROA. Hubungan ini menyatakan bahwa meskipun inflasi mengalami kenaikan, tetapi profitabilitas yang dihasilkan perbankan tidak terdapat perubahan. Hal ini dikarenakan kenaikan 
pendapatan debitur bank akan memudahkan debitur dalam membayar kewajibannya sehingga besarnya pendapatan bank sama dengan meningkatnya biaya operasional yang dibayarkan oleh bank yang disebabkan oleh inflasi sehingga profitabilitas yang dialami perbankan tidak terlalu tinggi (Adyatmika \& Wiksuana, 2018).

Penemuan ini sejalan dengan hasil penemuan Alim (2014), Zulfiah dan Susilowibowo (2014), Prasetiono (2016), Wireko dan Forson (2017), dan Haritsman dan Usman (2017).

\section{Hasil Koefisien Determinan}

Tabel 6

Hasil Uji Koefisien Determinan

\begin{tabular}{|c|c|}
\hline Variabel Dependen & Adjusted $\mathbf{R}^{\mathbf{2}}$ \\
\hline Return On Assets & 0,911691 \\
\hline
\end{tabular}

Sumber: Data penelitian diolah (2019)

Hasil uji koefisien determinan berfungsi untuk menjelaskan seberapa besar variabel independen menerangkan variabel dependen. Nilai adjusted $\mathrm{R}^{2}$ sebesar 0,911691 atau $91,17 \%$, artinya variabel ROA mampu dijelaskan oleh variabel independen CAR, NPL, bank size, liquidity, inefficiency, dan inflasi. Sisanya sebesar $8,83 \%$ dijelaskan oleh faktor atau variabel independen lain.

\section{KESIMPULAN}

Penelitian ini untuk mengetahui pengaruh manajemen risiko kredit terhadap profitabilitas BPR. Berdasarkan hasil penelitian dapat disimpulkan sebagai berikut:
1. Capital adequacy ratio memiliki pengaruh signifikan negatif terhadap profitabilitas.

2. Non performing loan memiliki pengaruh tidak signifikan terhadap profitabilitas.

3. Bank size memiliki pengaruh signifikan negatif terhadap profitabilitas.

4. Liquidity memiliki pengaruh signifikan positif terhadap profitabilitas.

5. Inefficiency memiliki pengaruh signifikan negatif terhadap profitabilitas.

6. Inflasi memiliki pengaruh tidak signifikan terhadap profitabilitas.

\section{DAFTAR PUSTAKA}

Abdeldayem, M. M., \& El-Sherbiney, R. A. (2018). A comparative study of the financial performance of the three banking modes in egypt: islamic, conventional and mixed banks. Archives of Business Research, 6, No. 5(5), 286308.

Adnan, Ridwan, \& Fildzah. (2016). Pengaruh ukuran bank, dana pihak ketiga, capital adequacy ratio, dan loan to deposit ratio terhadap penyaluran kredit pada perusahaan perbankan yang terdaftar di Bursa Efek Indonesia tahun 2011-2015. Jurnal Dinamika Akuntansi dan Bisnis, $3(2)$,

49-64. https://doi.org/10.24815/jdab.v3i2.5386

Adyatmika, I. G. P., \& Wiksuana, I. G. B. (2018). Pengaruh inflasi dan leverage terhadap profitabilitas dan return saham pada perusahaan manufaktur di BEI. Jurnal Ekonomi Dan Bisnis, 07(03), 615-648.

Afriyeni. (2017). Profitabilitas bank perkreditan rakyat di Kota Padang di tinjau dari rasio likuiditas. Jurnal Benefita, 2(1), 22-32. https://doi.org/10.22216/jbe.v2i1.2104

Agustini, N. L. P. B., Wiagustini, N. L. P., \& Purbawangsa, I. B. A. (2017). Pengaruh kecukupan modal dan risiko kredit terhadap profitabilitas: likuiditas sebagai pemediasi pada bank perkreditan rakyat di Kabupaten Badung. E-Jurnal Ekonomi Dan Bisnis, 6(6).

Al-Rdaydeh, M., Matar, A., \& Alghzwai, O. (2017). Analyzing the effect of credit and liquidity risks on profitability of conventional and islamic Jordanian banks. International Journal of Academic Research in Business and Social Sciences, 7(12). https://doi.org/10.6007/ijarbss/v7i12/3745

Alim, S. (2014). Analisis pengaruh inflasi dan BI rate terhadap return on assets (ROA) bank syariah di Indonesia. 10(3), 201-220. https://doi.org/http://dx.doi.org/10.2106 7/jem.v10i3.785 
Assfaw, A. M. (2018). Determinants of the financial performance of private commercial banks in Ethiopia: bank specific factors analysis. Global Journal of Management and Business Research, 18(3), 64-77.

Astrini, S., Suwendra, I. W., \& Suwarna, I. K. (2014). Pengaruh CAR, LDR dan bank size terhadap NPL pada lembaga perbankan yang terdaftar di Bursa Efek Indonesia. 2.

Attar, D., Islahuddin, \& Shabri, M. (2014). Pengaruh penerapan manajemen risiko terhadap kinerja keuangan perbankan yang terdaftar di Bursa Efek Indonesia. Jurnal Akuntansi, 3(Februari). https://doi.org/10.13140/RG.2.1.3589.4 882

Chou, T.-K., \& Buchdadi, A. D. (2016). Bank performance and its underlying factors: a study of rural banks in Indonesia. Accounting and Finance Research, 5(3), 55-63. https://doi.org/10.5430/afr.v5n3p55

Darayseh, M., \& Chazi, A. (2018). Bank specifics, economics environment, and agency theory: determinants of banking performance in GCC. The Journal of Developing Areas, 52(4), 199-212.

Hakimi, A., \& Zaghdoudi, K. (2017). Liquidity risk and bank performance: an empirical test for Tunisian banks. Business and Economic Research, 7(1), 46.

https://doi.org/10.5296/ber.v7i1.10524

Haritsman, E., \& Usman, B. (2017). Faktorfaktor yang mempengaruhi profitabilitas bank konvensional yang terdaftar di Bursa Efek Indonesia. Manajemen Bisnis, 12(1).

Indriantoro, N., \& Supomo, B. (2013). Metodologi penelitian bisnis untuk akuntansi \& manajemen. Yogyakarta: BPFE.

Ishak, I., Ismail, N., Razali, N. A., Bakar, R., \& Ramlan, H. (2016). Credit risk management and profitability of bank listed on bursa Malaysia. (May 2016).

Kadek Widya Astutiningsih, I. G. K. B. (2019). Pengaruh CAR, dana pihak ketiga, ukuran bank, dan LDR terhadap profitabilitas BPR. E-Jurnal Manajemen, $\quad 8(3), \quad$ 1608-1636. https://doi.org/https://doi.org/10.24843/ EJMUNUD.2019.v8.i3.p16

Kasmir. (2012). Bank dan lembaga keuangan lainnya. Jakarta: PT Raja Grafindo Persada.

Lelissa, T. B., \& Kuhil, A. M. (2018). Empirical evidence on the impact of bank-specific factors on the commercial banks performance: the CAMEL model and case Ethiopian banks. Global Journal of Management and Business Research: $\quad C \quad$ Finance, 18(5). https://doi.org/10.18843/rwjasc/v9i3/08

Lubis, F. A., Isynuwardhana, D., \& Juliana, V. (2017). Pengaruh loan to deposit ratio (LDR), non performing loan (NPL), capital adequacy ratio (CAR), net interest margin (NIM), biaya operasional pendapatan operasional (BOPO) terhadap return on asset. EProceeding of Management, 4(3), 2575-2584.

Maheswari, K. I., \& Sudirman, I. M. S. N. (2014). Pengaruh NPL terhadap ROA dengan mediasi CAR dan BOPO pada perbankan Indonesia. E-Jurnal Manajemen Universitas Udayana, 3(4), 1119-1139.

Mahmud, K., Mallik, A., Imtiaz, M. F., \& Tabassum, N. (2016). The bank-specific factors affecting the profitability of commercial banks in Bangladesh: a panel data analysis. International Journal of Managerial Studies and Research, 4(7), 67-74. https://doi.org/10.20431/23490349.0407008

Mendoza, R., \& Rivera, J. P. R. (2017). The effect credit risk and capital on the profitability of rural banks in the Philippines. Scientific Annals of Economics and Business, 64(1), 83-96. https://doi.org/10.1515/saeb-2017-0006

Mohanty, B. K., \& Krishnankutty, R. (2018). Determinant of profitability in Indian banks in the changing scenario. International Journal of Economics and 
Financial Issues, 8(3), 235-240.

Nihayati, A., Wahyudi, S., \& Syaichu, M. (2014a). Pengaruh ukuran bank, BOPO, risiko kredit, kinerja kredit, dan kekuatan pasar terhadap net interest margin (studi perbandingan pada bank persero dan bank asing periode tahun 2008-2012). Jurnal Bisnis Strategi, 23(2), 14-44.

Nihayati, A., Wahyudi, S., \& Syaichu, M. (2014b). Pengaruh ukuran bank, BOPO, risiko kredit, kinerja kredit dan kekuatan pasar terhadap net interest margin (studi perbandingan pada bank persero dan bank asing periode tahun 2008-2012). Jurnal Bisnis Strategi, 23(2), 14-44.

Ovami, D. C. (2017). Faktor-faktor yang mempengaruhi kinerja keuangan bank konvensional pada Bursa Efek Indonesia. Akuntansi dan Bisnis, 3(1), 23-28.

Pasaribu, R. B. F., Kowanda, D., \& Paramitha, G. N. P. (2015). Profitabilitas bank di Indonesia dengan metode risk based bank rating pada emiten perbankan di Bursa Efek Indoensia. Riset Akuntansi dan Keuangan, 11(1).

Prasetiono, E. A. K. (2016). Pengaruh struktur pasar, bank size, inflasi dan gross domestic product terhadap kinerja bank di ASEAN 5 (studi kasus bank komersial di ASEAN 5 periode tahun 2007-2014 ). Management, 5(4), 1-12.

Pratiwi, K. N. C., \& Suryantini, N. P. S. (2018). Pengaruh risiko bank terhadap profitabilitas bank BPR di Kota Denpasar. E-Jurnal Manajemen, 7(7). https://doi.org/10.24843/ejmunud.2018. v07.i07.p16

Putrianingsih, D. I., \& Yulianto, A. (2016). Pengaruh non performing loan (NPL) dan capital adequacy ratio (CAR) terhadap profitabilitas. Management Analysis, 5(2).

Saeed, \& Zahid. (2016). The impact of credit risk on profitability of the commercial banks. Journal of Business \& Financial
Affairs, $5(2)$.

https://doi.org/10.4172/2167-

0234.1000192

Sartono, A. (2014). Manajemen keuangan teori dan aplikasi (4th ed.). Yogyakarta: BPFE.

Sarwar, B., Mustafa, G., Abid, A., \& Ahmad, M. (2018). Internal and external determinant of profitability: a case of commercial banks of Pakistan. Journal of Commerce, Economics, and Social Sciences, $\quad 2, \quad 38-43$. https://doi.org/10.24312/paradigms1201 06

Septiani, R., \& Lestari, P. V. (2016). Pengaruh NPL dan LDR terhadap profitabilitas dengan CAR sebagai variabel mediasi pada PT BPR Pasar Raya Kuta. Manajemen, 5, 293-324. https://doi.org/10.1017/CBO978110741 5324.004

Syafi'i, M. F. R., \& Rusliati, E. (2016). Credit risk, market risk, operational risk and liquidity risk on profitability of banks in Indonesia. Trikonomika, 15(2), 78-88.

https://doi.org/10.23969/trikonomika.v1 $5 \mathrm{i} 2.387$

Wirawan, W., Jufrizen, \& Rambe, M. F. (2018). Pengaruh faktor internal dan eksternal terhadap kinerja perbankan pada bank umum yang terdaftar di Bursa Efek Indonesia. Ilmu Ekonomi Dan Studi Pembangunan, 18(1), 19-32.

Wireko, D., \& Forson, A. (2017). Credit risk management and profitability of selected rural banks in upper east region. Journal of Excellence, Leadership, \& Stewardship, 6(2), 4355.

Zulfiah, F., \& Susilowibowo, J. (2014). Pengaruh inflasi, BI rate, capital adequacy ratio (CAR), non performing finance (NPF), biaya operasional dan pendapatan operasional (BOPO) terhadap profitabilitas bank umum syariah periode 2008-2012. Jurnal Ilmu Manajemen, 2(3), 759-770. 